\title{
ESTIMATION OF PLASMA PHOSPHATASE BY DETERMINATION OF HYDROLYSED PHENOL WITH AMINO-ANTIPYRINE
}

\author{
BY \\ P. R. N. KIND AND E. J. KING \\ From the Postgraduate Medical School, London
}

(RECEIVED FOR PUBLICATION APRIL, 1954 ; ORIGINALLY SUBMITTED DECEMBER, 1951)

Plasma phosphatase was first determined by Martland (1925) and then by Kay (1930), using glycerophosphate and estimating the inorganic phosphate liberated at $37^{\circ} \mathrm{C}$. at a specified $p \mathrm{H}$ and in a given time. The procedure has been variously modified and simplified by Jenner and Kay (1932), Bodansky (1933), Shinowara, Jones, and Reinhart (1942). Several substrates, other than glycerophosphate, have also been used, e.g., phenyl phosphate (with determination of either the liberated phenol, King and Armstrong, 1934, or phosphate, King, Abul-Fadl, and Walker, 1951), nitro-phenyl phosphate (by the colour of the liberated nitrophenol, Ohmori, 1937 ; King and Delory, 1939 ; Bessey, Lowry, and Brock, 1946), naphthyl phosphate (by determination of naphthol by a diazo method, Seligman, Chauncey, Nachlas, Manheimer, and Ravin, 1951), phenolphthalein phosphate (by the colour of alkaline phenolphthalein, Bray and King, 1943 ; Huggins and Talalay, 1945). Of these procedures, the Bodansky (glycerophosphate) and the King-Armstrong (phenyl phosphate) are perhaps the most widely used.

King and Armstrong (1934) determined free phenol, liberated from phenyl phosphate by the phosphatase, by either the Folin and Ciocalteu (1927) phosphomolybdic reagent or by the diazo reaction, and preferred the former. Both procedures required the precipitation and removal of the plasma proteins subsequent to the hydrolysis of the substrate. In 1951 Grifols Lucas proposed a procedure for determination of the free phenol, which did not require removal of the proteins. This was based on the 4-amino-antipyrine reaction of Gottlieb and Marsh (1946).

In this method the conditions under which enzymic hydrolysis is carried out are the same as in the King-Armstrong method, as modified by King (1951), the amino-antipyrine reagent (A.A.P.) being used to estimate the phenol liberated.
4-Amino-antipyrine reacts with certain phenolic substances in the presence of alkaline oxidizing agents to produce quinonoid substitution products. These give a red colour proportional to the phenol present, and can be determined colorimetrically. Grifols-Lucas found that A.A.P. does not react with plasma proteins, and their removal is unnecessary when phosphatases are estimated.



4-Amino-antipyrine Phenol<smiles>[R]C(C)=C1C(=O)N(C)N(c2ccccc2)C1=O</smiles>

We investigated this method in 1951 , but delayed publication until the Grifols-Lucas communication should appear in full. As this has not been published so far as we know, and since findings similar to our own are now offered by Powell and Smith (1954), we now present our results. The original procedure has not been success- $\odot$ ful in our hands, due to interference by pro- $N$ teins with production of the red quinonoid colour, N but, by increasing the concentrations of reagents used, we have overcome this difficulty and have developed a method which is not far short of the King-Armstrong method in accuracy, and which $\stackrel{\mathcal{D}}{+}$ does not require precipitation and separation of 0 the plasma proteins, with a consequent simplification and shortening of the estimation. 


\section{Investigation of the Grifols-Lucas Procedure}

Method.-The method of GrifolsLucas is as follows :-

Test.-One millilitre $\mathrm{M} / 100 \mathrm{Na}_{2}$ phenyl phosphate +1 - ml. $\mathrm{Na}_{2} \mathrm{CO}_{3}: \mathrm{NaHCO}_{3}$ $(6: 4, p H 10)$ buffer warmed three min. at $37^{\circ} \mathrm{C} . ; 0.1 \mathrm{ml}$. plasma or serum added and mixed; kept at $37^{\circ}$ for 15 min.; $1 \mathrm{ml}$. $\mathrm{M} / 10 \mathrm{Na}_{2} \mathrm{CO}_{3}$ added and mixture removed to room temperature; $1 \mathrm{ml}$. $0.06 \%$ 4-amino-antipyrine (A.A.P.) and $1 \mathrm{ml} .0 .24 \%$ potassium ferricyanide $\left(\mathrm{K}_{3} \mathrm{Fe}(\mathrm{CN})_{6}\right)$ added and mixed.

Control.-Same as test, except that plasma is added after the $\mathrm{M} / 10 \mathrm{Na}_{2} \mathrm{CO}_{3}$.

Standard.-Standard phenol solution (0.02 mg. phenol), $1 \mathrm{ml}$., $+1.1 \mathrm{ml}$. $\mathrm{Na}_{2} \mathrm{CO}_{3}: \mathrm{NaHCO}_{3}$ buffer $+1 \mathrm{ml} . \mathrm{M} / 10$ $\mathrm{Na}_{2} \mathrm{CO}_{3}+1 \mathrm{ml} .0 .06 \%$ A.A.P. $+1 \mathrm{ml}$. $0.24 \% \mathrm{~K}_{3} \mathrm{Fe}(\mathrm{CN})_{6}$.

The colours develop immediately, and are read in a photoelectric colorimeter with an Ilford 624 green light filter.

\section{Calculation.-}

$\underset{\text { (units } / 100 \mathrm{ml} \text {.) }}{\text { Phosphatase }}=\frac{\text { Test }^{*}-\text { Control }^{*}}{\text { Standard* }} \times 0.02 \times \frac{100}{0.1}$

$$
\text { (* Readings in extinctions. } E \text { ) }
$$

Comparison of Method with King-Armstrong Procedure.-Twenty-six plasmas (or sera) from hospital routine specimens were analysed by this method in parallel with the King-Armstrong procedure. The

TABLE I

COMPARISON OF RESULTS OBTAINED BY KING (1951) AND GRIFOLS-LUCAS METHODS

\begin{tabular}{|c|c|c|}
\hline $\begin{array}{l}\text { King Method } \\
\text { (K.-A. units) }\end{array}$ & $\begin{array}{l}\text { Grifols-Lucas Method } \\
\text { (K.-A. units) }\end{array}$ & Ratio $\frac{\text { (K.) }}{\text { (G.L.) }}$ \\
\hline $\begin{array}{r}82 \cdot 0 \\
75 \cdot 0 \\
500 \\
49.0 \\
24 \cdot 0 \\
19 \cdot 2 \\
16 \cdot 4 \\
14 \cdot 2 \\
9 \cdot 8 \\
9 \cdot 8 \\
8 \cdot 3 \\
7 \cdot 9 \\
7 \cdot 8 \\
7 \cdot 4 \\
7 \cdot 2 \\
7 \cdot 2 \\
8 \cdot 2 \\
7 \cdot 3 \\
22.0 \\
12.1 \\
4.0 \\
4 \cdot 6 \\
61 \cdot 0 \\
25 \cdot 0 \\
14 \cdot 8 \\
33 \cdot 0\end{array}$ & $\begin{array}{r}83.0 \\
72.0 \\
49.0 \\
51.0 \\
22.0 \\
13.3 \\
13.3 \\
11.0 \\
8.0 \\
3.9 \\
8.2 \\
6.2 \\
7.4 \\
5.5 \\
5.4 \\
3.9 \\
5.7 \\
6.8 \\
18.4 \\
9.7 \\
1.6 \\
4.4 \\
38.0 \\
21.0 \\
11.9 \\
36.0\end{array}$ & $\begin{array}{l}0.99 \\
1.04 \\
1.02 \\
0.97 \\
1.09 \\
1.44 \\
1.23 \\
1.29 \\
1.22 \\
2.5 \\
1.01 \\
1.27 \\
1.05 \\
1.35 \\
1.34 \\
1.85 \\
1.44 \\
1.08 \\
1.2 \\
1.25 \\
2.5 \\
1.04 \\
1.6 \\
1.19 \\
1.25 \\
0.91\end{array}$ \\
\hline Average 26.4 & $19 \cdot 8$ & \\
\hline
\end{tabular}

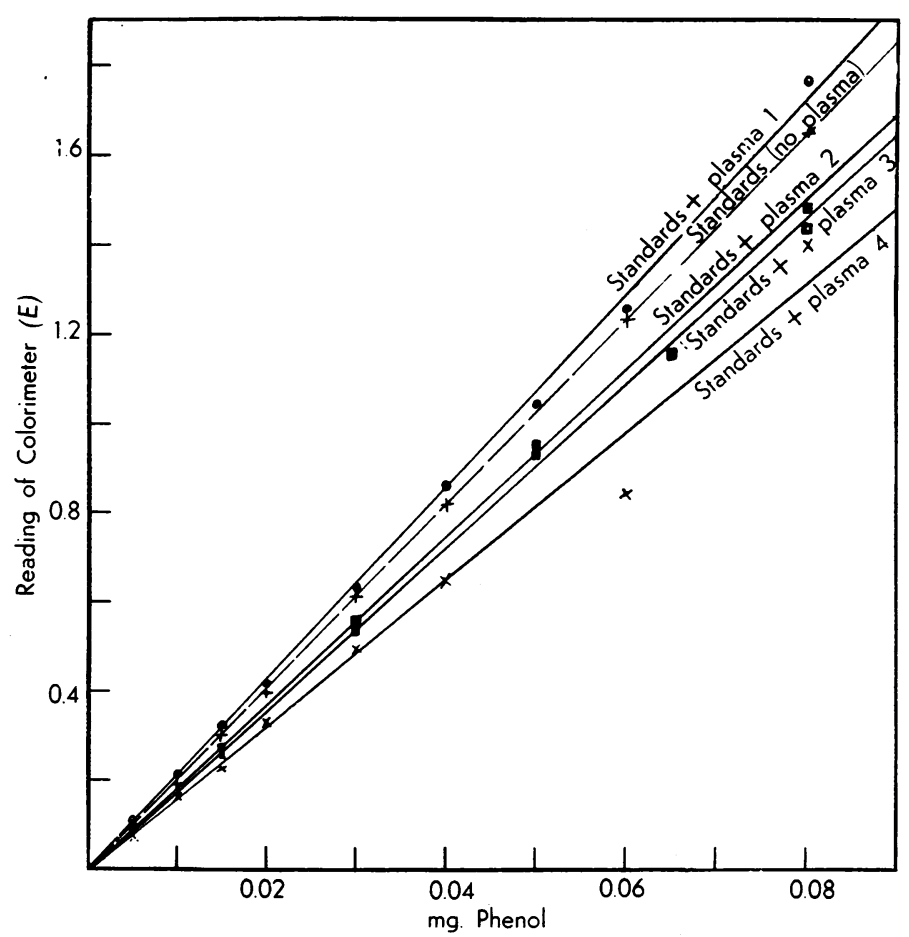

FIG. 1.-Effects of different plasmas on colour produced by different phenol standards.

results (Table I) were in poor agreement, with a wide scatter, the Grifols-Lucas figures ranging from $60 \%$ below the King-Armstrong to $10 \%$ above.

Effect on Colour of Added Plasma.-With the concentration of reagents used, the presence of plasma has a marked and variable effect on the colour produced in the reaction between phenol and aminoantipyrine (Fig. 1). It is therefore unsound to compare a test containing plasma proteins with a standard which does not. This difficulty was easily overcome by precipitating the plasma proteins (with tungstic acid) and removing them by centrifugation or filtration before adding the $\mathrm{Na}_{2} \mathrm{CO}_{3}$, A.A.P., and $\mathrm{K}_{3} \mathrm{Fe}(\mathrm{CN})_{6}$. The results then agreed well with the King-Armstrong, but the resulting procedure now had no advantage in simplicity and speed over the latter method.

We therefore sought to modify the method so that the proteins need not be precipitated, and the results nevertheless agree with those by the King-Armstrong procedure and with those for acid phosphatase as described by King (1951).

\section{Modification of the Method}

Arrest of Hydrolysis (at End of Incubation Period). -When using the existing Grifols-Lucas method for phosphatase estimations it was noticed that in some cases, particularly those with high phosphatase activity, the colour of both the test and control increased with time, while a standard containing plasma but no substrate gave a steady reading. This was almost 
certainly due to continuing phosphatase activity. The addition of $\mathrm{M} / 10 \mathrm{Na}_{2} \mathrm{CO}_{3}$ to bring the $p H$ to 10.2 , favourable for the colour reaction, had not inactivated the enzyme.

By adding a suitable amount of $\mathrm{N} / 2 \mathrm{NaOH}$ the $p \mathrm{H}$ could be raised, in both alkaline and acid phosphatase estimations, to $p H$ 11.5-11.6, thus destroying the enzyme; and by the addition of suitable amounts of $\mathrm{M} / 2 \mathrm{NaHCO}_{3}$ the $p \mathrm{H}$ could then be brought back to 10.2 (Table II).

\section{TABLE II}

EFFECT OF ADDITIONS OF NaOH (TO DESTROY PHOSPHATASE) AND OF $\mathrm{NaHCO}_{3}$ (TO PRODUCE $p \mathrm{H} 10.2$ FOR COLOUR DEVELOPMENT

\begin{tabular}{|c|c|c|}
\hline 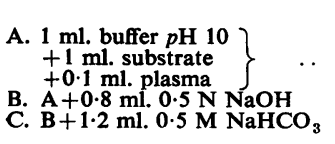 & $\cdots$ & \begin{tabular}{|c}
$p \mathrm{H}$ for Alkaline Phosphatase \\
10.0 \\
11.6 \\
$10 \cdot 2$
\end{tabular} \\
\hline 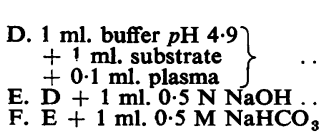 & $\cdots$ & $\begin{array}{c}p \mathrm{H} \text { for Acid Phosphatase } \\
5.0 \\
11.5 \\
10.2\end{array}$ \\
\hline
\end{tabular}

Effect on Colour Production in Phenol Standard of Various Strengths of A.A.P. and $\mathrm{K}_{3} \mathrm{Fe}(\mathrm{CN})_{6}$ - - GrifolsLucas's ratio of $1: 4$ was maintained in each case. Tests were prepared containing either $1 \mathrm{ml}$. of alkaline buffer $p \mathrm{H} 10$, or acid buffer $p \mathrm{H} 4.9$, to which were added $1 \mathrm{ml}$. of $0.01 \mathrm{mg} . / \mathrm{ml}$. standard. To the tests with alkaline buffer $0.8 \mathrm{ml}$. of $\mathrm{N} / 2 \mathrm{NaOH}$ and $1.2 \mathrm{ml}$. $\mathrm{M} / 2 \mathrm{NaHCO}_{3}$ were added, and to those with acid buffer $1 \mathrm{ml}$. N/2 $\mathrm{NaOH}$ and $1 \mathrm{ml}$. $\mathrm{M} / 2 \quad \mathrm{NaHCO}_{3}$ were added. To all were added $1 \mathrm{ml}$. of A.A.P. and $1 \mathrm{ml}$. of $\mathrm{K}_{3} \mathrm{Fe}(\mathrm{CN})_{6}$, the concentrations being varied as shown in Table III. The concentrations $0.6 \%$ A.A.P. and $2.4 \% \mathrm{~K}_{3} \mathrm{Fe}(\mathrm{CN})_{6}$ were chosen as mosit suitable for the colour reaction, as nearly similar readings were obtained with both alkaline and acid buffer, and a further increase in the strength of reagents appeared to have no advantage.

Calibration Curve Using Phenol Standards of Various Strengths.-Phenol standard, $1 \mathrm{ml}$., varying between $0.05 \mathrm{mg}$. and $0.005 \mathrm{mg}$., was mixed with $1 \mathrm{ml}$. alkaline buffer or $1 \mathrm{ml}$. acid buffer. The alkaline buffer standards were treated with $0.8 \mathrm{ml}$. of $\mathrm{N} / 2 \mathrm{NaOH}$ and $1.2 \mathrm{ml}$. of $\mathrm{M} / 2 \mathrm{NaHCO}_{3}$, and the acid with $1 \mathrm{ml}$. of $\mathrm{N} / 2 \mathrm{NaOH}$ and $1 \mathrm{ml}$. $\mathrm{M} / 2 \mathrm{NaHCO}_{3}$. To each was then added $1 \mathrm{ml}$. of $0.6 \%$ A.A.P. and $1 \mathrm{ml}$. of $2.4 \% \quad \mathrm{~K}_{3} \mathrm{Fe}(\mathrm{CN})_{6}$. After mixing the solutions the colours were measured using a 624 green Ilford light filter. The colours were first read
TABLE III

EFFECT ON COLOUR PRODUCTION IN A PHENOL STANDARD OF VARIOUS STRENGTHS OF A.A.P. AND $\mathrm{K}_{3} \mathrm{Fe}(\mathrm{CN})_{6}$

\begin{tabular}{c|c|c|c}
\hline \multicolumn{2}{c|}{ Concentration of } & \multicolumn{2}{c}{ Colorimetric Reading $(E \times 100)$} \\
\hline A.A.P. (\%) & $\mathrm{K}_{3} \mathrm{Fe}(\mathrm{CN})_{6}(\%)$ & Acid Buffer & Alkaline Buffer \\
\hline 0.06 & 0.24 & 11 & 9.0 \\
0.30 & 1.2 & 20 & 18.5 \\
0.60 & 2.4 & 23 & 22.0 \\
0.90 & 3.6 & 25 & 24.0 \\
1.2 & 4.8 & 32 & 27.0 \\
& & & \\
\hline
\end{tabular}

five min. after adding the reagents, and again after $15 \mathrm{~min}$. No alteration in colour intensity was observed. Fig. 2 shows a straight line in both alkaline and acid buffer, the two lines being nearly superimposed.

Effect of Adding Plasma to Standards in Modified Method.-The effect on colour production of adding $0.1 \mathrm{ml}$. of plasma to standards was tested. The averages of several determinations made at various times during this investigation are listed in Table IV. The alterations made in the concentrations of alkali, A.A.P., and $\mathrm{K}_{3} \mathrm{Fe}(\mathrm{CN})_{6}$ appear to have so minimized the effect of the plasma proteins on the colour that it can be ignored.

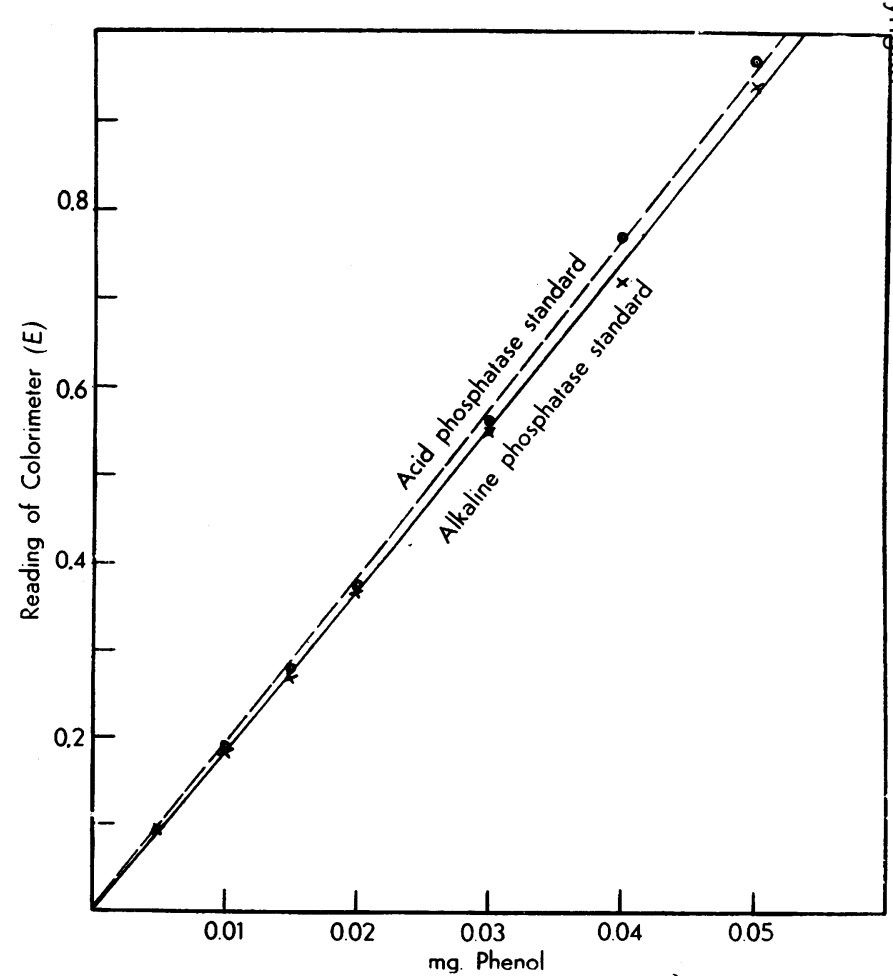

Fig. 2.-Calibration curve for phenol by modified A.A.P. colorimetric method. 
TABLE IV

EFFECT OF ADDING PLASMA TO STANDARDS IN THE MODIFIED METHOD

\begin{tabular}{|c|c|c|c|c|c|c|c|}
\hline \multirow{2}{*}{\multicolumn{2}{|c|}{$\begin{array}{c}\text { Stan- } \\
\text { dard } \\
\text { (mg. } \\
\text { phenol) }\end{array}$}} & \multirow{2}{*}{ No. } & \multirow{2}{*}{ Alkali Used } & \multicolumn{2}{|c|}{$\begin{array}{c}\text { Concentration } \\
\text { of }\end{array}$} & \multicolumn{2}{|c|}{$\begin{array}{l}\text { Average Read- } \\
\text { ing }(E)\end{array}$} \\
\hline & & & & 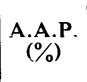 & $\begin{array}{l}\mathrm{K}_{3} \mathrm{Fe} \\
\left(\mathrm{CN}_{(\%)}\right. \\
(\%)\end{array}$ & $\begin{array}{l}\text { Stan- } \\
\text { dard + } \\
\text { Plas } n_{1}\end{array}$ & $\begin{array}{l}\text { Stan- } \\
\text { dard }\end{array}$ \\
\hline \multirow{3}{*}{ 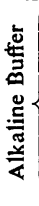 } & 0.02 & 20 & $1 \mathrm{ml} . \mathrm{M} / 10 \mathrm{Na}_{2} \mathrm{CO}_{3}$ & 0.06 & 0.24 & $0 \cdot 34$ & 0.37 \\
\hline & 0.01 & 20 & $\begin{array}{c}0.8 \mathrm{ml} . \mathrm{N} / 10 \mathrm{NaOH} \\
+1.2 \mathrm{ml} . \\
\mathrm{NaHCO}_{3}\end{array}$ & 0.6 & $2 \cdot 4$ & 0.27 & 0.23 \\
\hline & 0.01 & 12 & $\begin{array}{c}0.8 \mathrm{ml} . \mathrm{N} / 2 \mathrm{NaOH} \\
+1.2 \mathrm{ml} . \quad \mathrm{M} / 2 \\
\mathrm{NaHCO}_{3}\end{array}$ & 0.6 & $2 \cdot 4$ & 0.225 & 0.22 \\
\hline \multicolumn{2}{|c|}{ 事密 } & 20 & $\begin{array}{c}1 \mathrm{ml} . \\
+1 \\
\mathrm{NaHCO}_{3}\end{array}$ & 0.6 & $2 \cdot 4$ & $0 \cdot 236$ & 0.23 \\
\hline
\end{tabular}

\section{Modified Method Adopted}

Solutions.-The following are required :-

pH 10 Buffer.- $-\mathrm{M} / 10$ sodium carbonate-bicarbonate $\left(6 \mathrm{Na}_{2} \mathrm{CO}_{3}: 4 \mathrm{NaHCO}_{3}\right)$, for which $6.36 \mathrm{~g}$. anhydrous sodium carbonate and $3.36 \mathrm{~g}$. sodium bicarbonate are dissolved in distilled water and made to 1 litre.

pH 4.9 Buffer.-Crystalline citric acid, 21.0 g., is dissolved in water, $188 \mathrm{ml}$. N-NaOH added, and made to $500 \mathrm{ml}$. The $p \mathrm{H}$ should be checked and adjusted to $p \mathrm{H} 4.9$ if necessary by dropwise addition of $\mathrm{N}-\mathrm{NaOH}$ or $\mathrm{N}-\mathrm{HCl}$. This solution should be preserved with a few drops of chloroform and kept in the ice-chest.

Substrate.-M/100 disodium phenyl phosphate, $2.18 \mathrm{~g}$., is dissolved in 1 litre of water. The solution should be brought quickly to the boil to destroy any organisms, cooled immediately and preserved with a little chloroform.

Stock Phenol Standard (1 mg. per ml.).-Pure crystalline phenol, $1 \mathrm{~g}$., is dissolved in and made to 1 litre with $0.1 \mathrm{~N}-\mathrm{HCl}$.

Working Phenol Standards.-Standard, $0.01 \mathrm{mg} . /$ ml. : $1 \mathrm{ml}$., stock standard, diluted to $100 \mathrm{ml}$.; 0.03 $\mathrm{mg} . / \mathrm{ml}$. : $3 \mathrm{ml}$. stock standard diluted to $100 \mathrm{ml}$. Both working standards should be preserved with 2 or 3 drops of chloroform.

N/2 Sodium Hydroxide.-Standardized.

$M / 2$ Sodium Bicarbonate. $-\mathrm{NaHCO}_{3}, 4.2$ g., dissolved in water and made to $100 \mathrm{ml}$.

4-Amino-antipyrine (A.A.P. $0.6 \%$ ).-A.A.P., 0.6 g. is dissolved in water and made to $100 \mathrm{ml}$.

Potassium Ferricyanide. $-\mathrm{K}_{3} \mathrm{Fe}(\mathrm{CN})_{6}, 2.4 \mathrm{~g}$., is dissolved in water and made to $100 \mathrm{ml}$.

Methods for Alkaline and Acid Phosphatase.These are as follows:-

Test.-Buffer, $1 \mathrm{ml}$. ( $p \mathrm{H} 10$ for alkaline, $p \mathrm{H} 4.9$ for acid phosphatase), is added to $1 \mathrm{ml}$. substrate (M/100 $\mathrm{Na}_{2}$-phenyl phosphate), warmed at $37^{\circ} \mathrm{C}$. for three min., $0.1 \mathrm{ml}$. plasma added and mixed. The solution is incubated at $37^{\circ} \mathrm{C}$., $15 \mathrm{~min}$. for alkaline phosphatase (one hour for acid). Then $0.8 \mathrm{ml}$. N/2 $\mathrm{NaOH}$ is added for alkaline phosphatase $(1 \mathrm{ml} . \mathrm{N} / 2$ $\mathrm{NaOH}$ for acid), and $1.2 \mathrm{ml} . \mathrm{M} / 2 \mathrm{NaHCO}_{3}$ added for alkaline phosphatase $\left(1 \mathrm{ml}\right.$. $\mathrm{M} / 2 \mathrm{NaHCO}_{3}$ for acid). Then $1 \mathrm{ml} .0 .6 \%$ A.A.P. is added and mixed. Finally $1 \mathrm{ml}$. $2.4 \% \mathrm{~K}_{3} \mathrm{Fe}(\mathrm{CN})_{6}$ is added and mixed.

Control.-Same as test, except that plasma is added after the $\mathrm{NaOH}$.

Standards.-Alkaline (or acid) buffer, $1.1 \mathrm{ml}$., + $1 \mathrm{ml}$. phenol working standard $(0.01$ or $0.03 \mathrm{mg}$.) + $0.8 \mathrm{ml}$. N/2 NaOH $+1.2 \mathrm{ml}$. M/2 $\mathrm{NaHCO}_{3}$ for alkaline (or $1 \mathrm{ml}$. N/2 NaOH $+1 \mathrm{ml}$. M/2 $\mathrm{NaHCO}_{3}$ for acid) phosphatase standards $+1 \mathrm{ml} .0 .6 \%$ A.A.P. $+1 \mathrm{ml} .2 .4 \% \mathrm{~K}_{3} \mathrm{Fe}(\mathrm{CN})_{6}$.

Blank.-Same as standard, but water is substituted for phenol.

The colours develop immediately and are stable for at least an hour if kept in dim light.

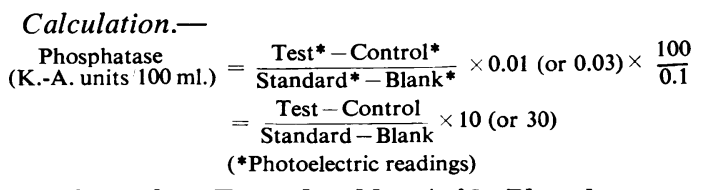

Method for Formol-stable Acid Phosphatase.These estimations are carried out in the same manner as those for total acid phosphatase, except that $0.02 \mathrm{ml}$. of neutral $40 \%$ formalin $(\mathrm{NaOH}$ added until pink to phenolphthalein) is added to the buffer-substrate

TABLE V

COMPARISON OF ALKALINE AND ACID PHOSPHATASE ACTIVITIES OF VARIOUS PATHOLOGICAL PLASMAS BY THE MODIFIED A.A.P. AND KING-ARMSTRONG METHODS

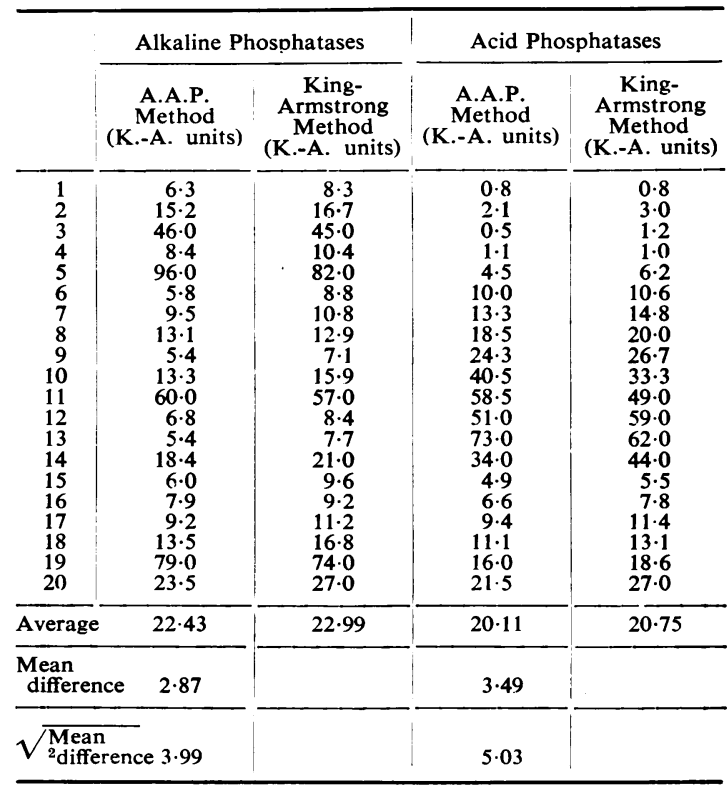


mixture of the test and control. The same amount of formalin is also added to the standard and blank, though this is unnecessary if a standard is already in use for total acid phosphatase, as formalin does not appear to alter the colour intensity.

\section{Comparison of Alkaline and Acid Phosphatase Activities of Various Pathological Plasmas by Modified A.A.P. and King-Armstrong Methods}

A series of alkaline and a series of acid phosphatase determinations were carried out by the modified A.A.P. method and the results compared with simultaneous determinations by the routine King-Armstrong procedure used in this laboratory (King, 1951). Table V shows that the agreement is as good as that usually obtained by enzymic methods. A comparison of results for formolstable acid phosphatase is given in Table VI.

TABLE VI

COMPARISON OF RESULTS OBTAINED FOR FORMOLSTABLE ACID PHOSPHATASE OF PLASMAS ESTIMATED BY A.A.P. AND KING-ARMSTRONG METHODS

\begin{tabular}{c|c}
\hline A.A.P. (K.-A. units) & King-Armstrong (K -A. units) \\
\hline 48.0 & 49.0 \\
10.2 & 10.6 \\
24.8 & 23.3 \\
18.9 & 18.1 \\
5.4 & 4.9 \\
5.9 & 4.3 \\
16.8 & 17.2 \\
28.2 & 29.5 \\
9.8 & 9.8 \\
33.8 & 33.0 \\
12.0 & 11.8 \\
41.5 & 39.0 \\
\hline Average .. 21.2 & 20.9 \\
\hline
\end{tabular}

The new method is simpler and somewhat quicker that the King-Armstrong, where precipitation and removal of proteins is necessary, and the results can be expressed in the same units.

\section{Summary}

A modified phenyl phosphate method for the determination of plasma alkaline and acid phosphatase is described. The liberated phenol is determined by reaction with 4-amino-antipyrine to yield a red-coloured quinone. This method, originally used by Grifols-Lucas, has been modified to yield results closely similar to those obtained by the King-Armstrong procedure. Results are expressed in the same K.-A. units.

\section{REFERENCES}

Bessey, O. A., Lowry, O. H., and Brock, M. J. (1946). J. biol. Chem., 164,321 .

Bodansky, A. (1933). Ibid., 101, 93

Bodansky, A. (1933). Ibid., 101, 93. Path. Bact., 55, 315

Bray, J., and King. E. J. (1943). J. Path. Bact., 55, 315.

Gottlieb, S., and Marsh, P. B. (1946). Ind. Engng Chem. Anal. Edit., $18,16$.

Grifols-Lucas, J. A. (1951). Brit. med. J., 2, 295. (Communication to International Congress of Clinic al Pathology.)

Huggins. C., and Talalay, P. (1945). J. biol. Chem., 159, 399.

Huggins.

Jenner, H. D., and Kay, H. D. (1932). Brit. J. exp. D. (1930). J. biol. Chem., 89, 235, 249.

King, E. J. (1951). Micro-Analysis in Medical Biochemistry, 2nd ed. Churchill, London

Abul-Fadl, M. A. M., and Walker, P. G. (1951). Journal Clinical Pathology, 4, 85.

_ and Armstrong, A. R. (1934). Canad. med. Ass. J., 31, 376. and Delory, G. E. (1939). Biochem. J., 33, 1185.

Martland, M. (1925). Ibid., 19, 117.

Ohmori, Y. (1937). Enzymologia, Amst., 4, 217.

Powell, M. E. A., and Smith, M. J. H. (1954). Journal of Clinical Pathology, 7, 245.

Seligman, A. M., Chauncey, H. H., Nachlas, M. M., Manheimer, L. H and Ravin, H. A. (1951), J. biol. Chem, 190, 7.

Shinowara, G. Y., Jones, L. M., and Reinhart, H. L. (1942). J. biol. Chem., 142, 921 . 